\title{
Platelets and Microtubules
}

\author{
EFFECT OF COLCHICINE AND $\mathrm{D}_{2} \mathrm{O}$ ON PLATELET AGGREGATION AND \\ RELEASE INDUCED BY CALCIUM IONOPHORE A23187
}

\author{
D. Menche, A. IsRael, and S. KarPatKin, Department of Medicine, \\ New York University Medical School, New York 10016
}

\begin{abstract}
A B S T R A C T We examined the role of microtubules in platelet aggregation and secretion (release reaction) induced by the calcium ionophore A23187 (0.8$5 \mu \mathrm{M})$. At these concentrations, platelet aggregation was preceded by a lag period of $\sim 1 \mathrm{~min}$. Colchicine (an agent that disrupts microtubule assembly-disassembly) was shown to bind to platelet microtubules by employing $\left[{ }^{3} \mathrm{H}\right]$ colchicine at a concentration that is specific for microtubules in other tissues $(10 \mathrm{nM})$. Colchicine prolonged the lag period, inhibited the secondary wave of platelet aggregation, and inhibited the release reaction (release of $\left[{ }^{14} \mathrm{C}\right]$ serotonin). Platelets were next incubated with $20-60 \% \mathrm{D}_{2} \mathrm{O}$, an agent that stabilizes microtubules. $\mathrm{D}_{2} \mathrm{O}$ overcame colchicineinduced inhibition of the lag period, aggregation, and release. $\mathrm{D}_{2} \mathrm{O}$ alone enhanced platelet aggregation by $59 \pm 14 \%$ (SEM) and shortened the lag period by $43 \pm 10 \%$. We conclude that functioning microtubules are required for platelet aggregation and release, and that microtubules of platelet preparations are functioning submaximally.
\end{abstract}

\section{INTRODUCTION}

The platelet is a cell whose major physiologic function, formation of a firm hemostatic plug, requires primary platelet aggregation by physiologic aggregating agents (collagen, ADP, thrombin, epinephrine); secretion of platelet contents (release reaction); and the irreversible secondary wave of platelet aggregation. This is accompanied by a change in platelet shape from disk to sphere (1). The secondary wave of platelet aggregation is preceded by, or associated with (2), the secretion of various platelet constituents such as ADP, $\mathrm{Ca}^{++}$,

Presented at the 63rd Annual Meeting of the American Society of Biological Chemistry, Dallas, Texas, 5 April 1979. Fed. Proc. 38: 2992a. A preliminary report appeared in 1978. Blood. 52(Suppl.): 271a.

Received for publication 12 July 1979 and in revised form 24 March 1980. and serotonin, which contribute to further propagation of the platelet plug. In other tissues, secretory events have been closely associated with microtubules $(3,4)$. Little is known of this association in platelets.

The role of microtubules has been postulated to be that of a supporting structure that helps maintain the platelet discoid shape (5). Its possible role in platelet secretion can be inferred from other studies using platelet aggregating agents and electron microscopy (6). A centripetal movement of circumferential microtubules and platelet granules before the release reaction has been described. Irreversible secondary platelet aggregation and release were associated with the apparent disappearance of centrally located microtubules (7). The secondary wave of platelet aggregation (induced by ADP or epinephrine) could be inhibited by "toxic" concentrations $(1 \mathrm{mM})$ of antimicrotubule agents that cause the apparent disappearance of microtubules under electron microscopy $(7,8)$, and that have additional properties other than their inhibition of microtubule assembly (9-16).

The purpose of this investigation was to study the role of microtubules in platelet aggregation induced by the $\mathrm{Ca}^{++}$ionophore $\mathrm{A} 23187$, as well as other aggregating agents, with concentrations of antimicrotubule agents that are specific for microtubules. The $\mathrm{Ca}^{++}$ionophore was employed because internal as well as external translocations of calcium are thought to trigger internal contractile events, as well as platelet release and aggregation $(17,18)$, and serotonin release from platelets by the $\mathrm{Ca}^{++}$ionophore has some characteristics of the physiologic release reaction (17).

\section{METHODS}

Platelet-rich plasma $(P R P)^{1}$ for platelet aggregation studies. PRP was obtained from laboratory volunteers who had not

${ }^{1}$ Abbreviation used in this paper: PRP, platelet-rich plasma. 
ingested any drugs for at least $1 \mathrm{wk}$. Whole blood was collected into $3.8 \%$ trisodium citrate (nine parts plus one part) in plastic tubes and centrifuged at $150 \mathrm{~g}$ for $5 \mathrm{~min}$ at room temperature in a desktop International centrifuge (International Equipment Co., Boston, Mass.). PRP was kept at room temperature for $30 \mathrm{~min}$ in tightly capped plastic tubes and then equilibrated at $37^{\circ} \mathrm{C}$ for $3 \mathrm{~min}$ before testing. Platelet-poor plasma was obtained by centrifuging the remainder of the blood at $2,000 \mathrm{~g}$ for $20 \mathrm{~min}$.

Aggregating agents. The aggregating agents used were dissolved in saline and diluted with $0.03 \mathrm{M}$ veronal buffer

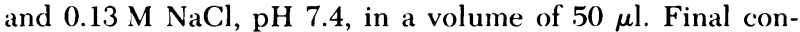
centrations were as follows: ADP disodium salt, $50 \mu \mathrm{M}$; epinephrine hydrochloride, $10 \mu \mathrm{M}$; connective tissue suspension prepared by the method of Zucker and Borrelli (19) and henceforth referred to as "collagen" at dilutions of $1: 8,000$ to $1: 16,000 ; \mathrm{Ca}^{++}$ionophore $\mathrm{A} 23187,0.8-5 \mu \mathrm{M}$.

Platelet aggregometry. Aggregometry was performed with platelet aggregating agents in a Bio-Data Aggregometer (BioData Corp., Willow Grove, Pa.) at $37^{\circ} \mathrm{C}$, using $0.50 \mathrm{ml}$ combined volume of PRP and reagents in a cylindrical glass cuvette $(0.8 \times 5 \mathrm{~cm})$ under constant stirring with a magnetic stirring bar. Platelet aggregation was measured turbidometrically by recording changes in the light transmission of PRP during aggregation. As platelets coalesce into larger aggregates, there is greater transmission of light, which is recorded by a downward deflection of the recording pen on a chart recorder (driven at a constant speed of $2.5 \mathrm{~cm} / \mathrm{min}$ ). Platelet aggregation was quantified by measuring the slope of the aggregation curve in units of percent transmission per minute $(\% \mathrm{~T} / \mathrm{min})$. The aggregometer was standardized automatically with platelet-poor plasma and PRP on a scale of $0-100 \%$ light transmission. Maximal percent transmission change, at $4 \mathrm{~min}$, was also measured on some occasions.

Serotonin release. $\left[{ }^{14} \mathrm{C}\right]$ Serotonin was dissolved in $70 \%$ ethanol to a concentration of $8 \mu \mathrm{Ci} / \mathrm{ml}$. PRP was prepared as above and incubated with $\left[{ }^{14} \mathrm{C}\right]$ serotonin at $37^{\circ} \mathrm{C}$ for $5 \mathrm{~min}, 1$ $\mu \mathrm{l}\left[{ }^{14} \mathrm{C}\right]$ serotonin/ml PRP. This PRP was then used for platelet aggregometry and for determination of percent serotonin release (platelet release reaction). Serotonin release was determined after addition of the aggregating agent for $4 \mathrm{~min}$. The PRP was centrifuged at $2,000 \mathrm{~g}$ for $10 \mathrm{~min}$ at $4^{\circ} \mathrm{C}$. A portion of the platelet-poor plasma obtained $(100 \mu \mathrm{l})$ was assayed for radioactivity in a Beckman LS100 scintillation spectrometer (Beckman Instruments, Inc., Fullerton, Calif.), and compared with the radioactivity obtained from a similar aliquot of uncentrifuged PRP. Blank radioactivity was obtained by centrifuging PRP that had not been exposed to the aggregating agent. This was subtracted from the platelet-poor plasma radioactivity obtained after platelet aggregation. Percent release was calculated by dividing the released radioactivity by the total PRP radioactivity and multiplying by 100 .

Incubation of platelets with $\left[{ }^{3} \mathrm{H}\right]$ colchicine. $1 \mathrm{U}$ of human PRP, collected in acid citrate dextrose, was obtained from the New York Blood Center. Platelets were sedimented at $2,500 \mathrm{~g}$ for $15 \mathrm{~min}$ at $4^{\circ} \mathrm{C}$, resuspended in $30 \mathrm{ml}$ of $1 \% \mathrm{am}$ monium oxalate, and allowed to sit at room temperature for 10 min. The platelets were then resedimented and washed with $10 \mathrm{ml}$ of Tris-buffered saline, $\mathrm{pH} 7.4$, containing $0.14 \mathrm{M}$ $\mathrm{NaCl}, 0.015 \mathrm{M}$ tris- $\mathrm{HCl}$, and $5.5 \mathrm{mM}$ glucose $(20)$; resuspended in $1 \mathrm{ml}$ of buffer (5-10\% volume suspension); and incubated in $17 \times 100-\mathrm{mM}$ polypropylene tubes (Falcon Labware, Div. of Becton, Dickinson, and Co., Oxnard, Calif.) at $37^{\circ} \mathrm{C}$, in the presence of $\left[{ }^{3} \mathrm{H}\right]$ colchicine, $1 \times 10^{6} \mathrm{cpm} / \mathrm{ml}$, for $60 \mathrm{~min}$.

Preparation of platelet cytoplasm. The platelets were sedimented at $2,000 \mathrm{~g}$ for $15 \mathrm{~min}$ at $4^{\circ} \mathrm{C}$ and washed three times with $10 \mathrm{ml}$ of buffer. Platelets were resuspended in $1 \mathrm{ml}$ of buffer and sonicated at $0^{\circ} \mathrm{C}$ with a Sonifier Cell Disruptor (Heat Systems-Ultrasonics, Inc., Plainview, N. Y.) at maximal intensity for two 15 -sec periods. The sonicated platelets were then centrifuged at $100,000 \mathrm{~g}$ for $1 \mathrm{~h}$ at $4^{\circ} \mathrm{C}$, using a Beckman model L Ultracentrifuge.

Molecular weight determination of protein bound to tritiated colchicine. The extract prepared above was applied to a calibrated Sephacryl S-200 gel filtration column (Pharmacia Diagnostics, Div. of Pharmacia, Inc., Piscataway, N. J.) and the molecular weight of the tritiated protein peak was determined with protein molecular weight standards (21): immunoglobulin $(155,000)$, bovine serum albumin $(68,000)$, ovalbumin $(43,000)$, and carbonic anhydrase $(29,000)$. Protein was monitored by $280 \mu \mathrm{m}$ absorbance. $\left[{ }^{3} \mathrm{H}\right] \mathrm{Colchicine}$ was assayed for radioactivity by scintillation counting.

Polyacrylamide gel electrophoresis of tritiated colchicine peak fraction. The fraction containing the peak radioactivity was concentrated by ultrafiltration under vacuum and electrophoresed under nondenaturing conditions. The gel was 7 $\mathrm{cm}$ long, $0.6 \mathrm{~cm}$ in diameter, and composed of $10 \%$ polyacrylamide with $0.28 \%$ cross-linkage in $0.1 \mathrm{M}$ phosphate buffer, $\mathrm{pH}$ 7.0. The procedure of Weber and Osborn (22) was followed, except for the absence of sodium dodecyl sulfate, using a Pharmacia gel electrophoresis apparatus,
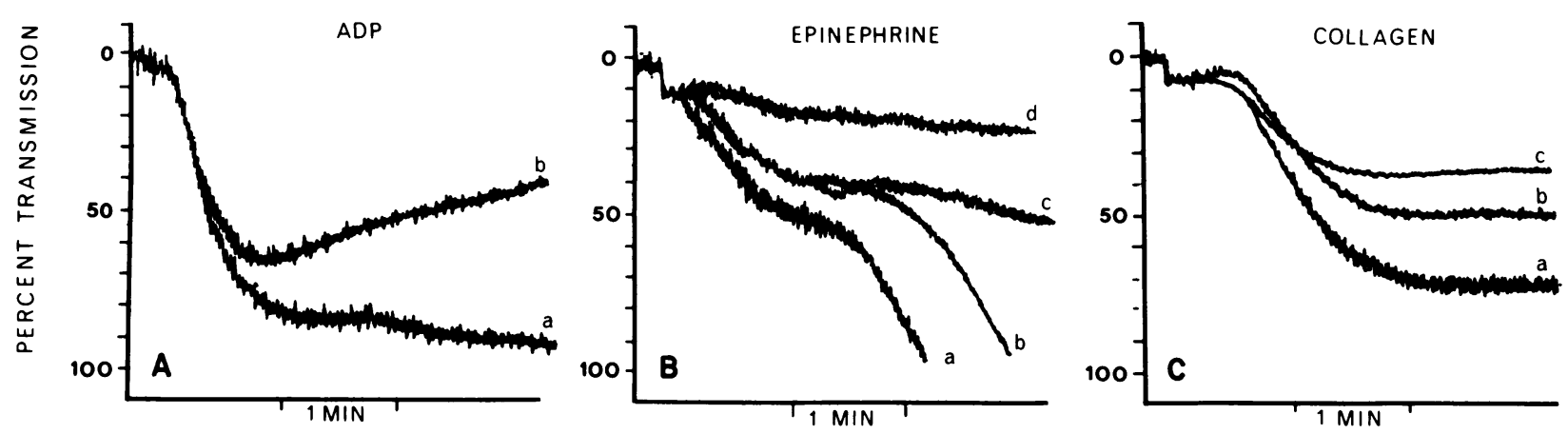

FIGURE 1 Effect of colchicine on platelet aggregation induced by ADP, epinephrine, or collagen. $0.4 \mathrm{ml}$ of PRP was incubated with varying concentrations of colchicine in a volume of $50 \mu \mathrm{l}$ for $2 \mathrm{~min}$ at $37^{\circ} \mathrm{C}$, followed by stirring with a magnetic stirring bar for $1 \mathrm{~min}$ and addition of $50 \mu \mathrm{l}$ of aggregating agent. (A) ADP, $0.05 \mathrm{mM} ; a$ and $b$ refer to 0 and $1 \mathrm{mM}$ colchicine, respectively. (B) Epinephrine, $0.01 \mathrm{mM} ; a, b, c$, and $d$ refer to $0,0.5,1$, and $2 \mathrm{mM}$ colchicine, respectively. (C) Collagen, 1:8,000 dilution; $a, b$, and $c$ refer to $0,0.25$, and $0.5 \mathrm{mM}$ colchicine, respectively. 
TABLE I

Additive Effect of Colchicine and Vinblastine on Platelet Aggregation Velocity Induced with $\mathrm{Ca}^{++}$Ionophore A23817*

\begin{tabular}{lccc}
\hline \multicolumn{1}{c}{ Experiment } & 1 & 2 & 3 \\
\hline & \multicolumn{3}{c}{ \% inhibition } \\
Colchicine, $1 \mathrm{mM}$ & 19 & 20 & 20 \\
Vinblastine, $0.06 \mathrm{mM}$ & 31 & 18 & 12 \\
Colchicine and vinblastine & 54 & 36 & 24 \\
Theoretical & 50 & 38 & 32 \\
\hline
\end{tabular}

* $0.35 \mathrm{ml}$ of PRP was mixed with $50 \mu \mathrm{l}$ of veronal buffer or used undiluted, and then incubated with either $50 \mu \mathrm{l}$ of colchicine, vinblastine, buffer, or colchicine plus vinblastine (100 $\mu \mathrm{l})$ for $8 \mathrm{~min}$ at $37^{\circ} \mathrm{C}$. This was followed by $1 \mathrm{~min}$ of stirring with a magnetic stirring bar, then the addition of $50 \mu \mathrm{l}$ of $\mathrm{Ca}^{++}$Ionophore at a final concentration of $2 \mu \mathrm{M}$. Percent inhibition refers to inhibition of control aggregation (buffer addition) performed in the absence of colchicine or vinblastine.

GE-14 (Pharmacia Inc.). The gel was equilibrated with buffer for $30 \mathrm{~min}$ at $5 \mathrm{~mA} / \mathrm{gel}$ before adding the sample. The sample was then run at $5 \mathrm{~mA} / \mathrm{gel}$ for $30 \mathrm{~min}$, to allow protein to penetrate the gel, and the amperage was then raised to $15 \mathrm{~mA} /$ gel for 3-4 h. The gel was stained with $0.25 \%$ Coomassie Blue (dissolved in $46 \%$ methanol-9\% glacial acetic acid) by immersing a test tube containing the gel and staining fluid in a boiling water bath for $15 \mathrm{~min}$. The gels were destained in $5 \%$ acetic acid- $35 \%$ ethanol at $56^{\circ} \mathrm{C}$ overnight. An unstained gel was fixed overnight in $46 \%$ methanol-9\% acetic acid,

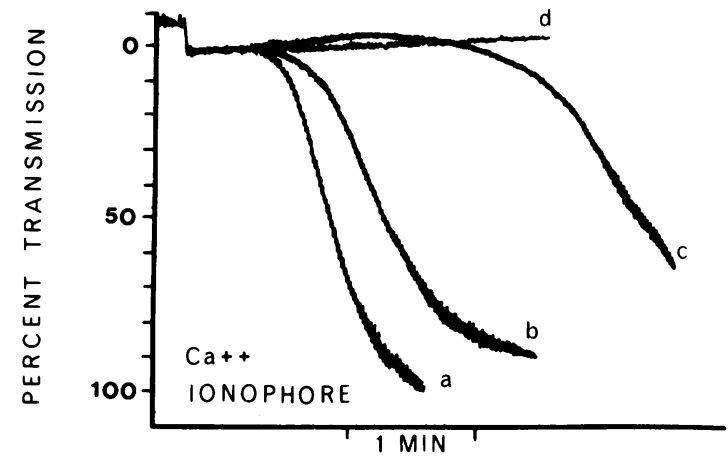

Figure 2 Effect of vinblastine on $\mathrm{Ca}^{++}$ionophore-induced platelet aggregation. PRP was diluted $1: 2$ in veronal buffer and $0.4 \mathrm{ml}$ of this suspension was incubated at $37^{\circ} \mathrm{C}$ for $4 \mathrm{~min}$ with $50 \mu \mathrm{l}$ of buffer solution containing indicated final vinblastine concentration. $a, b, c$, and $d$ refer to $0,0.04,0.08$, and $0.16 \mathrm{mM}$ vinblastine, respectively. The suspension was then stirred with a magnetic stirring bar for $1 \mathrm{~min}$, followed by addition of $50 \mu \mathrm{l}$ of $\mathrm{Ca}^{++}$ionophore at final concentration, $2 \mu \mathrm{M}$.

frozen with dry ice, and cut into 1-mm slices with a Brinkmann Gel Slicer (Brinkmann Instruments, Inc., Westbury, N. Y.). The gel slices were placed in scintillation vials, and $5 \mathrm{ml}$ of $3 \%$ Protosol-0.4\% Omnifluor in toluene was added (New England Nuclear, Boston, Mass.). The vials were maintained at $37^{\circ} \mathrm{C}$ for $3 \mathrm{~h}$ and then assayed for radioactivity by scintillation counting.

Materials. All materials were reagent grade. Colchicine, vinblastine, and $\mathrm{D}_{2} \mathrm{O}$ were obtained from Sigma Chemical Co., St. Louis, Mo. Lumicolchicine was prepared by exposure

TABLE II

Effect of $\mathrm{D}_{2} \mathrm{O}$ on Platelet Aggregation Velocity Induced by Calcium Ionophore A23187 and on Colchicine-induced Inhibition of Aggregation Velocity

\begin{tabular}{|c|c|c|c|c|c|c|}
\hline \multirow{3}{*}{$\begin{array}{c}\text { Number of } \\
\text { experiments }\end{array}$} & \multicolumn{6}{|c|}{ Aggregation velocity } \\
\hline & \multirow[b]{2}{*}{ Control } & \multicolumn{3}{|c|}{$\mathrm{D}_{2} \mathrm{O}$} & \multicolumn{2}{|c|}{$2 \mathrm{mM}$ Colchicine } \\
\hline & & $20 \%$ & $40 \%$ & $60 \%$ & + Buffer & $+30 \% \mathrm{D}_{2} \mathrm{O}$ \\
\hline & \multicolumn{6}{|c|}{$\%$ Transmission/min } \\
\hline 7 & $108 \pm 4.5$ & $\begin{array}{c}124 \pm 4.8 \\
(+15)^{*}\end{array}$ & & & & \\
\hline 4 & $122 \pm 9.3$ & & $\begin{array}{c}150 \pm 2.5 \\
(+23) \ddagger\end{array}$ & & & \\
\hline 7 & $80 \pm 7.6$ & & & $\begin{array}{c}127 \pm 16 \\
(+59) \ddagger\end{array}$ & & \\
\hline 5 & $127 \pm 6.6$ & & & & $\begin{array}{l}83 \pm 6.0 \\
(-35) \S\end{array}$ & $\begin{array}{r}106 \pm 9.2 \\
(-16)^{\prime \prime}\end{array}$ \\
\hline
\end{tabular}

$0.2 \mathrm{ml}$ of veronal buffer made up in $100 \% \mathrm{D}_{2} \mathrm{O}$ or $\mathrm{HOH}$ was mixed with $0.2 \mathrm{ml}$ of PRP to give varying concentrations of $\mathrm{D}_{2} \mathrm{O} .50 \mu \mathrm{l}$ of colchicine or buffer (dissolved in $\mathrm{H}_{2} \mathrm{O}$ or $\mathrm{D}_{2} \mathrm{O}$ ) was then added. The mixture was incubated at $37^{\circ} \mathrm{C}$ for $8 \mathrm{~min}$ and then stirred with a magnetic stirring bar for $1 \mathrm{~min}$, before the addition of $50 \mu \mathrm{l}$ of $\mathrm{Ca}^{++}$ionophore in $\mathrm{H}_{2} \mathrm{O}$ or $\mathrm{D}_{2} \mathrm{O}$ at final concentration, $1 \mu \mathrm{M}$. Percent change from control velocity is given in parentheses. $P$ values were obtained from a matched $t$ test.

${ }^{*} P<0.01$.

$\ddagger P<0.05$.

$\$ P<0.001$.

" Difference between colchicine and colchicine plus $30 \% \mathrm{D}_{2} \mathrm{O} . P<0.05$. 
TABLE III

Effect of Colchicine and $\mathrm{D}_{2} \mathrm{O}$ on $\left[{ }^{14} \mathrm{C}\right]$ Serotonin Release Induced by Ca ${ }^{++}$Ionophore A23187*

\begin{tabular}{|c|c|c|c|c|c|}
\hline \multirow[b]{2}{*}{ Experiment } & \multirow[b]{2}{*}{ Colchicine } & \multicolumn{4}{|c|}{ Percent release of serotonin } \\
\hline & & HOH buffer & $\mathrm{HOH}+$ alkaloid & $\mathrm{D}_{2} \mathrm{O}$ buffer & $\mathrm{D}_{2} \mathrm{O}+$ alkaloid \\
\hline & $\mu M$ & & & & \\
\hline \multirow[t]{2}{*}{1} & 100 & 34 & 7.6 & 29 & 35 \\
\hline & 200 & 34 & 0 & & 17 \\
\hline 2 & 100 & 24 & 7.1 & & 20 \\
\hline 3 & 500 & 62 & 13.0 & 42 & 32 \\
\hline 4 & 300 & 66 & 0 & & 20 \\
\hline \multirow[t]{4}{*}{5} & 100 & 42 & 30.0 & & \\
\hline & 200 & 42 & 27.0 & & \\
\hline & 300 & 42 & 13.0 & & \\
\hline & 400 & 42 & 0 & & 38 \\
\hline \multirow[t]{2}{*}{6} & 100 & 30 & 7.0 & 39 & \\
\hline & 200 & 30 & 0 & & 23 \\
\hline $7 \ddagger$ & 0.2 & $76 \pm 4.9$ & $5.1 \pm 2.8$ & $68 \pm 5.4$ & $63 \pm 8.4$ \\
\hline
\end{tabular}

* $0.2 \mathrm{ml}$ of PRP was diluted 1:1 with veronal buffer in $\mathrm{HOH}$ or $\mathrm{D}_{2} \mathrm{O}(60 \%$ final concentration) and preincubated for $4 \mathrm{~min}$ (in the presence or absence of $50 \mu \mathrm{l}$ of buffer or colchicine) before stirring with a magnetic stirring bar for $0.5 \mathrm{~min}$, followed by addition of $50 \mu \mathrm{l}$ of $\mathrm{Ca}^{++}$ionophore, final concentration $5 \mu \mathrm{M}$ (experiments 4 and $5,10 \mu \mathrm{M}$ ).

$\$ 1 \mathrm{~h}$ preincubation with colchicine, $\mathrm{HOH}$ buffer, $\mathrm{D}_{2} \mathrm{O}$ buffer, or $\mathrm{D}_{2} \mathrm{O}$ buffer plus colchicine at $37^{\circ} \mathrm{C}$, before addition of $\mathrm{Ca}^{++}$ionophore (mean of six experiments $\pm \mathrm{SEM}$ ).

of colchicine to UV light. Epinephrine hydrochloride was obtained from Parke-Davis, Detroit, Mich. $\mathrm{Ca}^{++}$ionophore A23187 was a gift from Eli Lilly and Co., Indianapolis, Ind., and was dissolved in dimethyl sulfoxide. $\left[2-{ }^{14} \mathrm{C}\right]$ Serotonin, $30 \mathrm{mCi} / \mathrm{mmol}$, was obtained from Amersham and Searle, Arlington Heights, Ill. $\left[{ }^{3} \mathrm{H}\right]$ Colchicine, $10-20 \mathrm{Ci} / \mathrm{mmol}$, was obtained from New England Nuclear, Boston, Mass. All reagents for polyacrylamide gels were obtained from Bio-Rad Laboratories, Richmond, Va. Sephacryl S-200 was obtained from Pharmacia Inc., Piscataway, N. J. Purified human brain tubulin was a gift from Dr. L. Liebes, New York University Medical School.

\section{RESULTS}

Effect of colchicine on platelet aggregation induced by ADP, epinephrine, and collagen. Fig. $1 a, b$, and $c$ demonstrate the inhibitory effect of preincubation of 0.25-2 $\mathrm{mM}$ colchicine for $2 \mathrm{~min}$ on platelet aggregation induced by ADP, epinephrine, or collagen, confirming initial observations of White (7) as well as others $(23,24)$. As can be noted, this inhibition affects the secondary wave of platelet aggregation more than the primary wave.

Effect of colchicine or vinblastine on platelet aggregation induced by $\mathrm{Ca}^{++}$ionophore A23187. Calcium ionophore-induced platelet aggregation at $<5 \mu \mathrm{M}$ was preceded by a lag period which in all studies was followed by a single wave of platelet aggregation. Fig. 2 demonstrates the effect of $0.04-0.16 \mathrm{mM}$ vinblastine on $\mathrm{Ca}^{++}$ionophore-induced aggregation. This prolonged the lag phase by $33-72 \%$, and impaired platelet aggregation velocity. Similar results were obtained with colchicine, which was found to be 20- to 40-fold less potent on a molar basis. For example, $1.5 \mathrm{mM}$ colchicine inhibited the aggregation velocity by $31 \pm 1.1 \%$ (SEM) and increased the lag period by $37 \pm 2.7 \%$ ( 12 experiments, $P<0.001$ ). Similar results were obtained with $0.04 \mathrm{mM}$ vinblastine, which inhibited the velocity of aggregation by $28 \pm 1.5 \%$ and

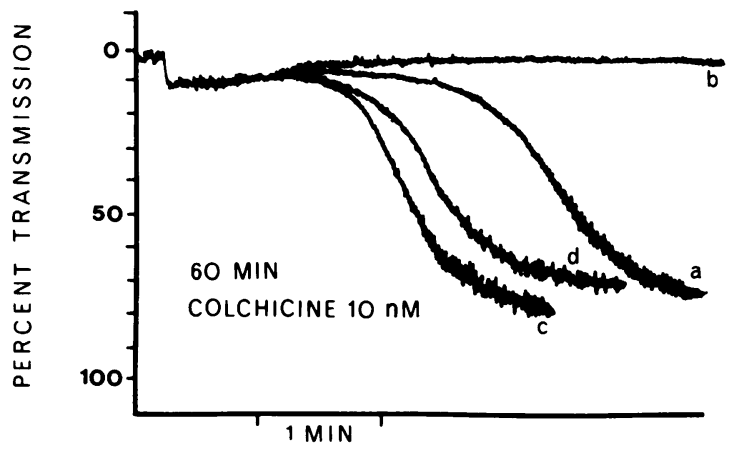

FIGURE 3 Effect of preincubation of platelets with $10 \mathrm{nM}$ colchicine for $1 \mathrm{~h}$ on platelet aggregation with veronal buffer. $(a)$ $0.4 \mathrm{ml}$ of PRP (diluted 1:1 with veronal buffer) was incubated with $50 \mu$ l of veronal buffer for $1 \mathrm{~h}$ at $37^{\circ} \mathrm{C}$, followed first by stirring with a magnetic stirring bar for $1 \mathrm{~min}$, then the addition of $\mathrm{Ca}^{++}$ionophore in $50 \mu \mathrm{l}$ at final concentration, 0.8 $\mu \mathrm{M}$. (b) Same as in $a$, except that veronal buffer contained colchicine to yield a final concentration of $10 \mathrm{nM}$. (c) Same as in $a$, except that platelets were preincubated for $1 \mathrm{~h}$ with veronal buffer made up in $\mathrm{D}_{2} \mathrm{O}$ to yield a final concentration of $50 \%$ $\mathrm{D}_{2} \mathrm{O}$, at $37^{\circ} \mathrm{C}$. (d) Same as in $c$, except that veronal buffer also contained colchicine at $10 \mathrm{nM}$. 


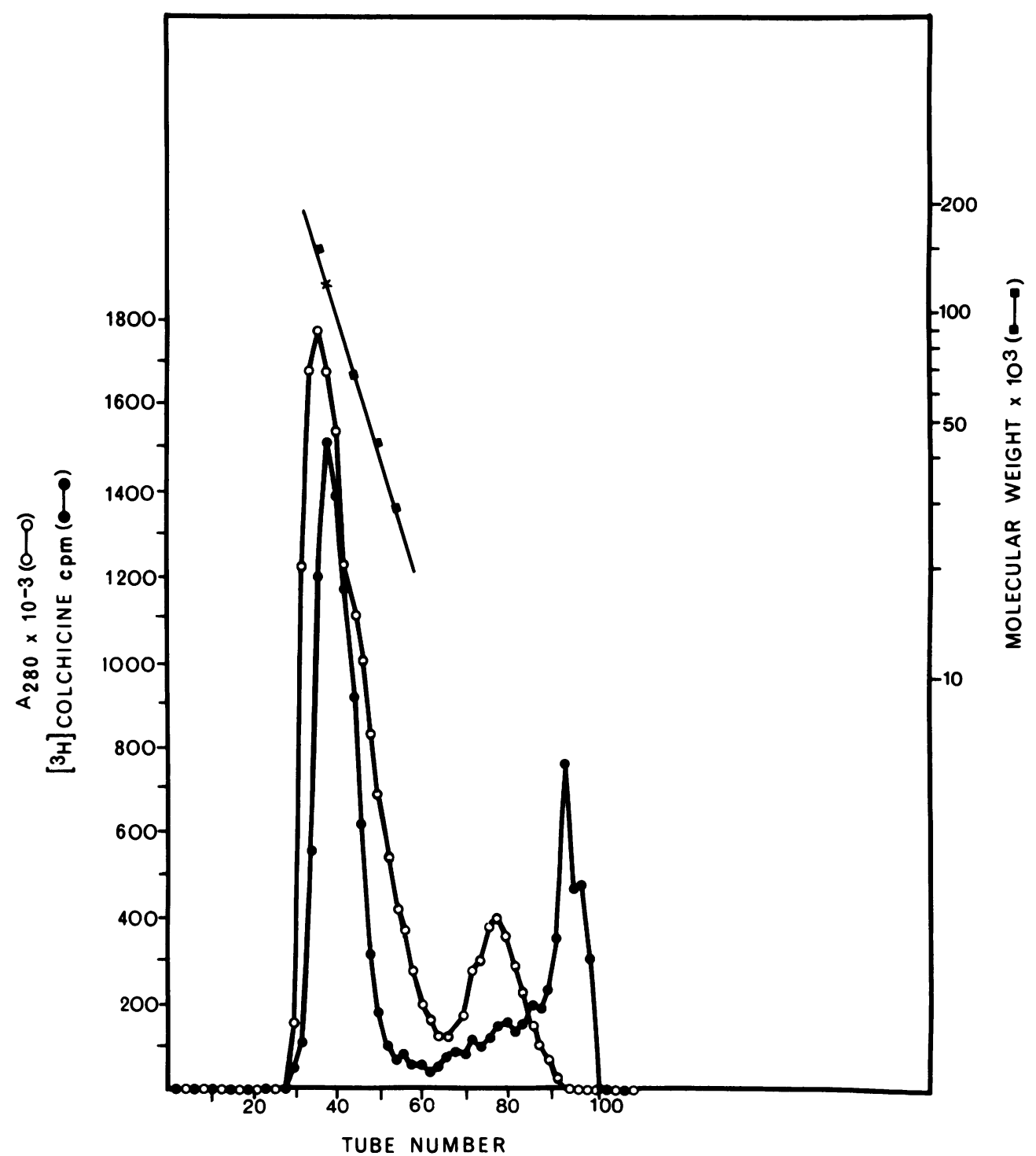

FIGURE 4 Binding of $10 \mathrm{nM}$ colchicine to platelet tubulin. Platelets were incubated in the presence of $10 \mathrm{nM}$ tritiated colchicine, $1 \mathrm{million} \mathrm{cpm} / \mathrm{ml}$, for $1 \mathrm{~h}$, and the cell sap was prepared as cited in Methods. $1 \mathrm{ml}$ of the cell sap was applied to a calibrated ( $\square$ ) Sephacryl-200 gel filtration column, $1.0 \times 28 \mathrm{~cm}$, and the effluent $(0.5-\mathrm{ml}$ fractions) monitored for radioactivity $(0)$ and 280 $\mu \mathrm{m}$ absorbance (O). Peak radioactivity was obtained at an apparent molecular weight of 110,000. Free tritiated colchicine peaked at tube number 94 .

increased the lag period by $33 \pm 2.5 \%$ (Five experiments, $P<0.001)$. The effect of both colchicine and vinblastine was additive (Table $\mathrm{I}$ ).

Effect of $\mathrm{D}_{2} \mathrm{O}$ and colchicine on platelet aggregation and release of serotonin induced by $\mathrm{Ca}^{++}$ionophore A23187. $\mathrm{D}_{2} \mathrm{O}$, an agent known to stabilize microtubules in other tissues, shortened the $\mathrm{Ca}^{++}$ionophore-induced lag period by $43 \pm 10 \%$ and increased the velocity of platelet aggregation by $59 \pm 14 \%(P$ $<0.05$ ) at a $\mathrm{D}_{2} \mathrm{O}$ concentration of $60 \%$ (average of seven experiments). Similar changes were noted at $40 \%$ $(P<0.05)$ and $20 \%(P<0.01) \mathrm{D}_{2} \mathrm{O}$ (Table II). The combination of $\mathrm{D}_{2} \mathrm{O}$ and colchicine apparently corrected the alkaloid-induced inhibition of platelet aggregation velocity and prolonged the lag period (Table II). For example, $2 \mathrm{mM}$ colchicine inhibited the $\mathrm{H}_{2} \mathrm{O}$ control by $35 \%(P<0.001)$, whereas inhibition (16\%) was negligible in the presence of $30 \% \mathrm{D}_{2} \mathrm{O}$ $(P<0.1)$. Similar results were obtained with the lag period (data not shown). 


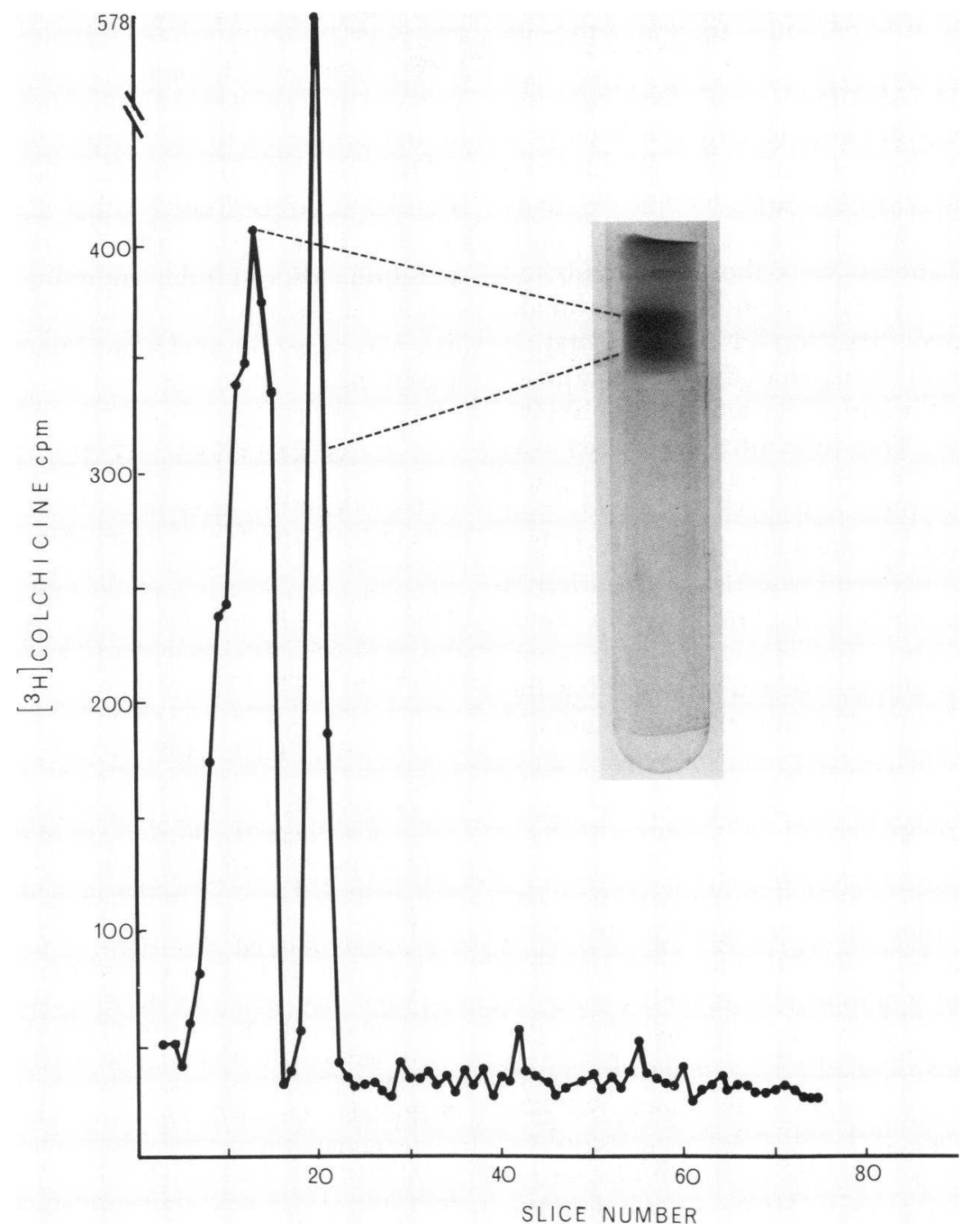

FIGURE 5 Electrophoresis of tritiated colchicine peak fraction from Fig. 4 on 10\% polyacrylamide gel in $0.1 \mathrm{M}$ phosphate buffer, $\mathrm{pH}$ 7.0. The gel was fixed, frozen, sliced, monitored for radioactivity, and compared with a similar gel on which a purified brain tubulin standard was applied (inset). The two radioactive ( $)$ monomer components of tubulin, $\alpha$ and $\beta$, were electrophoresed at the same position as purified brain tubulin standard.

Table III demonstrates the effect of colchicine and $\mathrm{D}_{2} \mathrm{O}$ on the platelet release reaction. Thus, $\left[{ }^{14} \mathrm{C}\right]-$ serotonin release was inhibited by colchicine at $0.1-$ $0.5 \mathrm{mM}$ (experiments 1-6), after addition of $\mathrm{Ca}^{++}$ ionophore at 5-10 $\mu \mathrm{M} . \mathrm{D}_{2} \mathrm{O}(40 \%)$ partially to completely prevented the colchicine-induced inhibition of $\left[{ }^{14} \mathrm{C}\right]$ serotonin release.

Effect of 10 or $100 \mathrm{nM}$ colchicine on platelet aggregation and release. Since colchicine at $0.1 \mathrm{mM}$ does not inhibit platelet aggregation after 2 min of preincubation, we examined the possible effect of longer preincubation at lower colchicine concentration on platelet aggregation and release. Fig. 3 demonstrates that after preincubation for $1 \mathrm{~h}, 10 \mathrm{nM}$ colchicine does in- hibit platelet aggregation, compared with a control incubation. ${ }^{2} \mathrm{D}_{2} \mathrm{O}$ alone shortened the lag period and enhanced aggregation velocity. $\mathrm{D}_{2} \mathrm{O}$ plus colchicine completely overcame the inhibition of $10 \mathrm{nM}$ colchicine (representative of five experiments). In similar experiments, low concentration of colchicine $(0.1 \mu \mathrm{M})$ also inhibited platelet release of serotonin.(Lumicolchicine an agent that does not bind tubulin, at $0.1 \mu \mathrm{M}$ had no effect). $\mathrm{D}_{2} \mathrm{O}$ plus colchicine overcame this inhibition (Table III, experiment 7). Lysis of serotoninloaded control platelets in $\mathrm{D}_{2} \mathrm{O}$ buffer gave similar

\footnotetext{
${ }^{2}$ It is of interest to note that $0.5 \mu \mathrm{M}$ colchicine has been shown to inhibit platelet spreading on glass slides (25).
} 
release, as did lysis of serotonin-loaded platelets in $\mathrm{H}_{2} \mathrm{O}$ buffer.

Binding of $10 \mathrm{nM}$ colchicine to platelet tubulin. Since $10 \mathrm{nM}$ colchicine does not lead to disassembly of microtubules in platelets, as indicated by electron microscopy, whereas $0.1-1.0 \mathrm{mM}$ colchicine does (7), we examined whether colchicine at $10 \mathrm{nM}$ binds to platelet tubulin. Platelets were therefore incubated in the presence of $\left[{ }^{3} \mathrm{H}\right]$ colchicine and the cell sap applied to a calibrated Sephacryl-200 gel filtration column. Fig. 4 demonstrates that the peak radioactivity was obtained at a molecular weight of 110,000 , that of tubulin dimer. This peak of radioactivity was then concentrated by filtration under vacuum, applied to a nondenaturing $10 \%$ polyacrylamide gel, and electrophoresed in $0.1 \mathrm{M}$ phosphate buffer at $\mathrm{pH}$ 7.0. The gel was frozen and sliced, and the distribution of radioactivity was compared with a brain tubulin standard simultaneously run. The two monomer components of tubulin, $\alpha$ and $\beta$, coelectrophoresed at the same position as purified brain tubulin standard (Fig. 5).

\section{DISCUSSION}

The role of microtubules in platelet aggregation has been relegated to that of a supporting structure, maintaining the platelet's discoid shape (5). In other tissues, inhibition of microtubule assembly impairs secretory events $(3,4)$. Previous work by White (7), employing toxic doses of alkaloids, revealed impaired platelet aggregation, particularly secondary aggregation. These toxic doses $(0.1-1.0 \mathrm{mM})$ were required for the disappearance of platelet microtubules, as indicated by electron microscopy. However, the pharmocologic dosage of colchicine used in the treatment of gout is in the $1-\mu \mathrm{M}$ range, and concentrations of 10 $\mu \mathrm{M}$ are fatal (26). Furthermore, in vitro concentrations of colchicine in the 10-1000 $\mu \mathrm{M}$-range are known to affect other cellular processes $(9-16)$.

It was therefore necessary to determine whether colchicine impairs platelet aggregation by reacting with microtubules, and whether colchicine also inhibits platelet secretion. This was accomplished by three approaches. First, concentrations of colchicine were employed that were fairly specific for microtubules in other tissues $(27,28)$. Platelets were incubated with colchicine at 10 and $100 \mathrm{nM}$ for $60 \mathrm{~min}$ before addition of the aggregating agent, $\mathrm{Ca}^{++}$ionophore A23187. This dose was also noted to inhibit secretion of platelet serotonin. Second, $\mathrm{D}_{2} \mathrm{O}$, a known stabilizer of microtubules, nullified the colchicineinduced inhibition of platelet aggregation and secretion. Furthermore, $60 \% \mathrm{D}_{2} \mathrm{O}$ alone also enhanced by $59 \%$ platelet aggregation induced by $\mathrm{Ca}^{++}$ionophore and reduced the lag period by $43 \%$. These data sug- gest that microtubules of platelet preparations are functioning submaximally. Third, $\left[{ }^{3} \mathrm{H}\right]$ colchicine at $10 \mathrm{nM}$ was shown to bind specifically to platelet microtubules when incubated with intact platelets.

Thus, colchicine, which binds to platelet microtubules at concentrations that are specific for microtubules, inhibits secondary platelet aggregation and secretion. Microtubules therefore not only provide a supporting structure for platelet discoid shape, but are also necessary for secondary platelet aggregation and secretion.

\section{ACKNOWLEDGMENTS}

The authors are indebted to Mr. Reace Stanford for expert technical assistance. We thank Ms. Bea Grofe for the illustrations.

This experiment was supported by grant NHLBI 13336-10 of the National Heart, Lung, and Blood Institute, and contract DADA 17-68-C-8163 from the U. S. Army Research and Development Command.

\section{REFERENCES}

1. Zucker, M. B. 1977. Platelet Function in Hematology. W. J. Williams, E. Beutler, A. J. Erslev, and R. W. Rundles, editors. McGraw-Hill Book Co. New York. 1200-1209.

2. Charo, I. F., R. D. Feinman, and T. C. Detwiler. 1977. Interrelations of platelet aggregation and secretion. $J$. Clin. Invest. 60: 866-873.

3. Olmsted, J. B., and G. G. Borisy. 1973. Microtubules. Annu. Rev. Biochem. 42: 507-540.

4. Stephens, R. E., and K. T. Edds. 1976. Microtubules: structure, chemistry, and function. Physiol. Rev. 56: 709-777.

5. Behnke, O. 1965. Further studies on microtubules. A marginal bundle in human and rat thrombocytes. $J$. Ultrastruct. Res. 13: 469-477.

6. White, J. G. 1968. Fine structural changes induced in platelets by adenosine diphosphate. Blood. 31: 604-622.

7. White, J. G. 1969. Effects of colchicine and vinca alkaloids on human platelets I. Influence on platelet microtubules and contractile function. Am. J. Pathol. 53: 281-291.

8. White, J. G. 1969. Effects of colchicine and vinca alkaloids on human platelets. III. Influence on primary internal contraction and secondary aggregation. Amer. J. Pathol. 54: 467-478.

9. Ehrlich, H. P., R. Ross, and P. Bornstein. 1974. Effects of antimicrotubular agents on the secretion of collagen. $J$. Cell Biol. 62: 390-405.

10. Patzelt, C., D. Brown, and B. Jeanrenaud. 1977. Inhibitory effect of colchicine on amylase secretion by rat parotid glands. J. Cell Biol. 73: 578-593.

11. Trifaro, J. M., B. Collier, A. Lastowecka, and D. Stern. 1972. Inhibition by colchicine and vinblastine of acetylcholine-induced catecholamine release from an adrenal gland: an anticholinergic action, not an effect upon microtubules. Mol. Pharmacol. 8: 264-267.

12. Mizell, S. B., and L. Wilson. 1972. Nucleoside transport in mammalian cells. Inhibition by colchicine. Biochemistry. 11: 2573-2578.

13. Harris, E. J., Jr., and S. M. Krane. 1971. Effect of colchicine on collagenase in cultures of rheumatoid synovium. Arthritis Rheum. 14: 669-684.

14. DeChatelet, C. R., M. R. Cooper, and C. E. McCall. 
1971. Dissociation by colchicine of the hexosemonophosphate shunt activation from the bactericidal activity of the leukocyte. Infect. Immun. 3: 66-72.

15. Krishan, A., and D. Hsu. 1971. Vinblastine-induced ribosomal complexes. J. Cell Biol. 49: 927-932.

16. Goldfinger, S. E., R. R. Howell, and J. E. Seegmiller. 1965. Suppression of metabolic accompaniments of phagocytosis by colchicine. Arthritis Rheum. 8: 11121122.

17. Feinstein, M. B., and C. Fraser. 1975. Human platelet secretion and aggregation induced by calcium ionophores. Inhibition by $\mathrm{PGE}_{1}$ and dibutyl cyclic AMP. J. Gen. Physiol. 66: 561-581.

18. Massini, P., and E. F. Luscher. 1974. Some effects of ionophores for divalent cations on blood platelets. Comparison with effects of thrombin. Biochim. Biophys. Acta. 372: 109-121.

19. Zucker, M. B., and J. Borrelli. 1962. Platelet clumping produced by connective tissue suspensions and by collagen. Proc. Soc. Exp. Biol. Med. 109: 779-787.

20. Lyons, R. M., N. Stanford, and P. W. Majerus. 1975. Thrombin-induced protein phosphorylation in human platelets. J. Clin. Invest. 56: 924-936.

21. Andrews, P. 1964. Estimation of the molecular weights of proteins by sephadex gel filtration. Biochem. J. 91: $222-233$.

22. Weber, K., and M. Osborn. 1969. The reliability of molecular weight determinations by dodecylsulfate polyacrylamide gel electrophoresis. J. Biol. Chem. 244: 4406-4412.

23. Soppitt, G. D., and J. R. A. Mitchell. 1969. The effect of colchicine on human platelet behaviour. J. Atheroscler. Res. 10: 247-252.

24. Sneddon, J. M. 1971. Effect of mitosis inhibitors on blood platelet microtubules and aggregation. J. Physiol. 214: 145-158.

25. Boyle-Kay, M. M. B., and H. H. Fudenberg. 1973. Inhibition and reversal of platelet activation by cytochalasin B or colcemid. Nature (Lond.). 244: 288-289.

26. Goodman, L. S., and A. Gilman. 1975. The Pharmacological Basis of Therapeutics. L. S. Goodman and A. Gilman, editors. MacMillan, Inc. New York. 350.

27. Olmsted, J. B., and G. G. Borisy. 1973. Characterization of microtubule assembly in porcine brain extracts by viscometry. Biochemistry. 12: 4282-4289.

28. Margolis, R. L., and L. Wilson. 1977. Addition of colchicine-tubulin complex to microtubule ends: the mechanism of substoichiometric colchicine poisoning. Proc. Natl. Acad. Sci. U. S. A. 74: 3466-3470. 